\title{
Heterobimetallics of Nickel-Iron Dinitrosyl: Electronic Control by Chelate and Diatomic Ligands
}

\author{
Wen-Feng Liaw, ${ }^{*} \dagger$ Chao-Yi Chiang, ${ }^{\dagger}$ Gene-Hsiang Lee, ${ }^{\ddagger}$ Shie-Ming Peng, \\ Chia-Huei Lai, ${ }^{\S}$ and Marcetta Y. Darensbourg*,\$
}

Department of Chemistry, National Changhua University of Education, Changhua 50058, Taiwan, Department of Chemistry \& Instrumentation Center, National Taiwan University, Taipei 10764, Taiwan, and Department of Chemistry, Texas A\&M University, College Station, Texas 77843

Received June 2, 1999

\begin{abstract}
Reaction of [PPN] $\left[\mathrm{Fe}(\mathrm{NO})_{2}(\mathrm{SePh})_{2}\right](\mathbf{1})$ with dimeric $\left[\mathrm{Ni}\left(\mu-\mathrm{SCH}_{2} \mathrm{CH}_{2} \mathrm{SCH}_{2} \mathrm{CH}_{2} \mathrm{~S}\right)\right]_{2}$ in the presence of additional $\mathrm{NO}_{2}{ }^{-}$produced the neutral heterobimetallic $\left[(\mathrm{ON}) \mathrm{Ni}\left\{\left(\mu-\mathrm{SCH}_{2} \mathrm{CH}_{2}\right)_{2} \mathrm{~S}\right\} \mathrm{Fe}(\mathrm{NO})_{2}\right]$ complex (2). The X-ray crystal structures of $\mathbf{1}$ and $\mathbf{2}$ show distorted tetrahedral iron dinitrosyl groups, assigned according to the Feltham-Enemark notation as $\left\{\mathrm{Fe}(\mathrm{NO})_{2}\right\}^{9}$. The $\mathrm{Fe}-\mathrm{NO}$ bonds are off linearity by an average of $\approx 10^{\circ}$ for compounds $\mathbf{1}$ and $\mathbf{2}$, while a more linear $\mathrm{Ni}-\mathrm{NO}$ coordination with a Ni-NO distance of $1.644(2) \AA$ was found in 2 . The $v(\mathrm{NO})$ value of complex 2 is consistent with an assignment for $\{\mathrm{Ni}(\mathrm{NO})\}^{9}$ of $\mathrm{Ni}^{0}(\mathrm{NO})^{+}$as is known for analogous phosphine derivatives, $\mathrm{P}_{3} \mathrm{Ni}^{0}(\mathrm{NO})^{+}$. EPR signals of $g$ values $=2.02-2.03$ confirmed the existence of the odd electron in the chalcogenated $\left\{\mathrm{Fe}(\mathrm{NO})_{2}\right\}^{9}$ compounds. Two $\left\{\mathrm{Fe}(\mathrm{NO})_{2}\right\}^{10}$ complexes coordinated by the nickel(II) dithiolate, (bismercaptoethanediazacyclooctane)nickel(II), (Ni-1), (Ni-1)Fe(CO)(NO) $)_{2}$ and $(\mathbf{N i}-1) \mathrm{Fe}(\mathrm{NO})_{2}$, were prepared for comparison to the $\mathrm{Ni}^{0}(\mathrm{NO})^{+}$derivative and other monomeric and homodimetallic derivatives of the $\mathrm{Fe}(\mathrm{NO})_{2}$ fragment. While the oxidation level of $\mathrm{Fe}(\mathrm{NO})_{2}$ is the primary determinant of $v(\mathrm{NO})$ values, they are also highly sensitive to ancillary ligands and, thereby, the distal metal influence through the bridging thiolate donor.
\end{abstract}

\section{Introduction}

The selective synthesis of heterobimetallic complexes presents challenges, particularly in the area of thiolate-bridged $\mathrm{M}(\mu$ $\mathrm{SR})_{2} \mathrm{M}^{\prime}$ systems where ideal precursors are apt to exist as stable polynuclear species and product speciation into homopolynuclear compounds is also prevalent. Interesting targets of this type are in biomimicry of the $(\mathrm{CysS})_{2} \mathrm{Ni}(\mu \text {-SCys })_{2} \mathrm{Fe}(\mathrm{CN})_{2}(\mathrm{CO})$ active site of $[\mathrm{NiFe}] \mathrm{H}_{2}$ ase, intriguing for the heterobimetallic site and also for the initial observation of nature's use of diatomic ligands in catalytically active site construction. ${ }^{1}$ Since then, the $\mathrm{Fe}$-only $\mathrm{H}_{2}$ ase has likewise been established to contain diatomic ligands in its binuclear active site..$^{2,3}$ While the origin and role of the diatomic ligands are as much a question as is the requirement for two metals in the active site, two different metals in the case of $[\mathrm{NiFe}] \mathrm{H}_{2}$ ase, advances in understanding are expected to result from the advantages offered by diatomic

\footnotetext{
* To whom correspondence should be addressed.

$\dagger$ National Changhua University of Education.

$\doteqdot$ National Taiwan University.

$\S$ Texas A\&M University.

(1) (a) Volbeda, A.; Charon, M.-H.; Piras, C.; Hatchikian, E. C.; Frey, M.; Fontecilla-Camps, J. C. Nature 1995, 373, 580. (b) Volbeda, A.; Garcin, E.; Piras, C.; de Lacey, A. L.; Fernandez, V. M.; Hatchikian, E. C.; Frey, M.; Fontecilla-Camps, J. C. J. Am. Chem. Soc. 1996, 118, 12989. (c) de Lacey, A. L.; Hatchikian, E. C.; Volbeda, A.; Frey, M.; Fontecilla-Camps, J. C.; Fernandez, V. M. J. Am. Chem. Soc. 1997, 119, 7181. (d) Garcin, E.; Vernede, X.; Hatchikian, E. C.; Volbeda, A.; Frey, M.; Fontecilla-Camps, J. C. Structure 1999, 7, 557.

(2) (a) Pierik, A. J.; Hulstein, M.; Hagen, W. R.; Albracht, S. P. J. Eur. J. Biochem. 1998, 258, 572. (b) Van Dam, P. J.; Reijerse, E. J.; Hagen, W. R. Eur. J. Biochem. 1997, 248, 355. (c) Van Der Spek, T. M.; Arendsen, A. F.; Happe, R. P.; Yun, S.; Bagley, K. A.; Stufkens, D. J.; Hagen, W. R.; Albracht, S. P. J. Eur. J. Biochem. 1996, 237, 629.

(3) (a) Nicolet, Y.; Piras, C.; Legrand, P.; Hatchikian, C. E.; FontecillaCamp, J. C. Structure 1999, 7, 13. (b) Peters, J. W.; Lanzilotta, W. N.; Lemon, B. J.; Seefeldt, L. C. Science 1998, 282, 1853.
}

ligands as spectroscopic probes if well-characterized model complexes are made available.

Recently, Osterloh and co-workers reported that a $\mathrm{Ni}(\mu$ $\mathrm{SR})_{2} \mathrm{Fe}(\mathrm{NO})_{2}$ heterobimetallic was produced upon displacement of two carbonyls of $\mathrm{Fe}(\mathrm{CO})_{2}(\mathrm{NO})_{2}$ by a square planar $\mathrm{N}_{2} \mathrm{~S}_{2}$ complex of $\mathrm{Ni}(\mathrm{II}){ }^{4}$ The resultant iron dinitrosyl unit maintained quite low $v(\mathrm{NO})$ values of $<1700 \mathrm{~cm}^{-1}$, as in its precursor $\mathrm{Fe}$ $(\mathrm{CO})_{2}(\mathrm{NO})_{2}$, where the iron nitrosyl unit has the formal electron assignment, $\left\{\mathrm{Fe}(\mathrm{NO})_{2}\right\}^{10}$. This formalism invokes the Enemark-Feltham notation which stresses the well-known covalency and delocalization in the electronically amorphous $\mathrm{Fe}(\mathrm{NO})_{2}$ unit, without committing to a formal oxidation state on $\mathrm{Fe}$, that is, assignments to $\mathrm{Fe}^{\mathrm{II}}\left(\mathrm{NO}^{-}\right)_{2}, \mathrm{Fe}^{0}(\mathrm{NO})_{2}, \mathrm{Fe}^{-\mathrm{II}}\left(\mathrm{NO}^{+}\right)_{2}$, or some mixture thereof. ${ }^{5}$ By application of our stepwise ligand exchange route, and with the use of a flexible $S_{3}$ precursor of $\mathrm{Ni}(\mathrm{II})$ in the presence of nitrite anion, we have prepared a second $\mathrm{Ni}(\mu-\mathrm{SR})_{2} \mathrm{Fe}(\mathrm{NO})_{2}$ unit, complex 2 below, and report it herein as an example of formal oxidation state assignments of $\mathrm{Ni}^{0}$ $\left\{\mathrm{Fe}(\mathrm{NO})_{2}\right\}^{9}$.

Examples of nitric oxide coordination to iron and the spectroscopic signals of dinitrosyl iron complexes (DNIC) are of much interest, particularly in light of their role(s) in sulfurrich protein uptake and degradation. ${ }^{6}$ Furthermore, DNICs have been suggested as possible forms for stabilization and transport of NO in biological systems. ${ }^{7}$ Thus, the precursor to the heterobimetallic complex $2,(\mathrm{PhSe})_{2} \mathrm{Fe}(\mathrm{NO})_{2}{ }^{-}$, (complex 1), was also isolated and characterized by X-ray crystallography and infrared spectroscopy. To address the heterometal influence on

(4) Osterloh, F.; Saak, W.; Haase, D.; Pohl, S. Chem. Commun. 1997, 979.

(5) Enemark, J. H.; Feltham, R. D. Coord. Chem. Rev. 1974, 13, 339.

(6) Foster, M. W.; Cowan, J. A. J. Am. Chem. Soc. 1997, 121, 44093.

(7) Vanin, A. F. Biochem. (Moscow) 1998, 63, 782. 
Table 1. Summary of Crystallographic Data for $[\mathrm{PPN}]\left[\mathrm{Fe}(\mathrm{NO})_{2}(\mathrm{SePh})_{2}\right](\mathbf{1})$ and $\left[(\mathrm{ON}) \mathrm{Ni}\left(\mu-\mathrm{S}\left(\mathrm{CH}_{2}\right)_{2} \mathrm{~S}\left(\mathrm{CH}_{2}\right)_{2} \mathrm{~S}\right) \mathrm{Fe}(\mathrm{NO})_{2}\right](2)$

\begin{tabular}{|c|c|c|}
\hline & 1 & 2 \\
\hline empirical formula & $\mathrm{C}_{48} \mathrm{H}_{40} \mathrm{O}_{2} \mathrm{~N}_{3} \mathrm{P}_{2} \mathrm{FeSe}_{2}$ & $\mathrm{C}_{4} \mathrm{H}_{8} \mathrm{O}_{3} \mathrm{~N}_{3} \mathrm{~S}_{3} \mathrm{NiFe}$ \\
\hline fw $(\mathrm{g} / \mathrm{mol})$ & 966.57 & 356.86 \\
\hline temp, $\mathrm{K}$ & 298 & 298 \\
\hline wavelength, $\AA$ & 0.7107 & 0.7107 \\
\hline cryst syst & monoclinic & triclinic \\
\hline space group & $C 2 / c$ & $P \overline{1}$ \\
\hline \multirow[t]{2}{*}{ unit cell dimensions } & $a=16.769(4) \AA$ & $\begin{array}{l}a=7.0616(12) \AA ; \\
\alpha=96.809(10)^{\circ}\end{array}$ \\
\hline & $\begin{array}{l}b=14.972(4) \AA \\
\beta=100.36(3)^{\circ} \\
c=18.019(5) \AA\end{array}$ & $\begin{array}{l}b=7.4228(11) \AA ; \\
\beta=93.367(11)^{\circ} \\
c=11.4142(12) \AA ; \\
\gamma=95.630(12)^{\circ}\end{array}$ \\
\hline vol, $\AA^{3}$ & $4450.2(20)$ & $589.71(15)$ \\
\hline$Z$ & 4 & 2 \\
\hline$\rho_{\text {calc }}, \mathrm{Mg} / \mathrm{m}^{3}$ & 1.443 & 2.010 \\
\hline$R(F)[I>2 \sigma(I)],{ }^{a} \%$ & 3.7 & 2.6 \\
\hline $\mathrm{wR}\left(F^{2}\right)$ all data, ${ }^{a} \%$ & 3.2 & 3.8 \\
\hline
\end{tabular}

adjacent metal diatomics, analogues of the Osterloh et al. complex ${ }^{4}$ based on (bismercaptoethanediazacyclooctane)nickel(II), (bme-daco)Ni(II), Ni-1, as the metallothiolate ligand to $\{\mathrm{Fe}-$ $\left.(\mathrm{NO})_{2}(\mathrm{CO})\right\}$ and $\left\{\mathrm{Fe}(\mathrm{NO})_{2}\right\}$ were prepared and their spectroscopic signals compared with a host of monomeric and homodimetallic derivatives of the $\mathrm{Fe}(\mathrm{NO})_{2}$ fragment. The ability to reference the $\mathrm{Fe}(\mathrm{NO})_{2}$ moiety within a consistent framework permits conclusions regarding the electronic character of the metal-modified ancillary ligands.

\section{Experimental Section}

General Methods and Materials. Solvents were reagent grade and were purged by nitrogen prior to use. All syntheses and product isolations were carried out under $\mathrm{N}_{2}$ using standard Schlenk and glovebox techniques.

Physical Measurements. Infrared spectra were recorded on a BioRad FTS-185 instrument using a 0.1-mm-spaced $\mathrm{KBr}$ sealed cell. Elemental analyses were carried out by a CHN analyzer (Heraeus). EPR spectra were measured on a Bruker ESP 300 spectrometer equipped with an Oxford ER910A cryostat at $100 \mathrm{~K}$. The spin concentration for each EPR sample was determined by the comparison of the double integral of the entire EPR spectrum of the sample with that of a standard, that is, $1 \mathrm{mM} \mathrm{Cu}$ (II) in $10 \mathrm{mM} \mathrm{EDTA}^{8}$ Electrochemical measurements were performed by a BAS-100A electroanalyzer utilizing glassy carbon working, $\mathrm{Ag} / \mathrm{AgNO}_{3}$ reference, and platinum auxiliary electrodes. Cyclic voltammograms were obtained from $2.5 \mathrm{mM}$ analyte concentration in $\mathrm{CH}_{2} \mathrm{Cl}_{2}$ using $0.1 \mathrm{M}\left[n-\mathrm{Bu}_{4} \mathrm{~N}\right]-$ $\left[\mathrm{PF}_{6}\right]$ as a supporting electrolyte. Potentials were scaled to NHE using ferrocene as an internal standard. ${ }^{9}$

The X-ray crystal structures were solved at the Department of Chemistry and Instrumentation Center at National Taiwan University, Taipei, Taiwan. X-ray crystallographic data were obtained on a Nonius CAD 4 diffractometer with graphite-monochromated Mo K $\alpha$ radiation employing the $\theta / 2 \theta$ scan mode. A $\varphi$ scan absorption correction was made. Structural determinations were made using the NRCC-SDP-VAX package of programs. Cell parameter and data collection summaries for $[\mathrm{PPN}]\left[\mathrm{Fe}(\mathrm{NO})_{2}(\mathrm{SePh})_{2}\right](\mathbf{1})$ and $\left[(\mathrm{ON}) \mathrm{Ni}\left(\mu-\mathrm{S}\left(\mathrm{CH}_{2}\right)_{2} \mathrm{~S}\left(\mathrm{CH}_{2}\right)_{2} \mathrm{~S}\right) \mathrm{Fe}-\right.$ $\left.(\mathrm{NO})_{2}\right](2)$ are given in Table 1.

(8) Orme-Johnson, N. R.; Orme-Johnson, W. H. Methods Enzymol. 1978, $52,252$.

(9) Gagne, R. R.; Koval, C. A.; Lisensky, G. C. Inorg. Chem. 1980, 19, 2854 .
Syntheses. Complexes $\left[\mathrm{Ni}\left(\mu \text {-S }\left(\mathrm{CH}_{2}\right)_{2} \mathrm{~S}\left(\mathrm{CH}_{2}\right)_{2} \mathrm{~S}\right)\right]_{2},{ }^{10}[\mathrm{PPN}]\left[\left[\mathrm{Fe}(\mathrm{CO})_{3^{-}}\right.\right.$ $\left.(\mathrm{SePh})_{3}\right],{ }^{11} \mathrm{Fe}(\mathrm{NO})_{2}(\mathrm{CO})_{2},{ }^{12}$ and (bme-daco) $\mathrm{Ni}(\mathrm{II})^{13}$ were synthesized by published procedures. ( $\mathrm{PPN}=$ bis triphenylphosphineiminium cation).

Preparation of $[\mathrm{PPN}]\left[\mathrm{Fe}(\mathrm{NO})_{2}(\mathrm{SePh})_{2}\right](\mathbf{1})$. The compound [PPN]$\left[\left[\mathrm{Fe}(\mathrm{CO})_{3}(\mathrm{SePh})_{3}\right](0.2 \mathrm{mmol}, 0.115 \mathrm{~g})\right.$ was loaded into a $100-\mathrm{mL}$ Schlenk flask with $0.028 \mathrm{~g}(0.4 \mathrm{mmol})$ of $\mathrm{NaNO}_{2}$, and $30 \mathrm{~mL}$ of THF was added. The reaction mixture was stirred at $50{ }^{\circ} \mathrm{C}$ for $24 \mathrm{~h}$, after which $15 \mathrm{~mL}$ of hexane was added. The resulting mixture was filtered to separate the yellow precipitate, $\mathrm{NaSePh}$. Upon solvent removal in vacuo from the filtrate, $[\mathrm{PPN}]\left[\mathrm{Fe}(\mathrm{NO})_{2}(\mathrm{SePh})_{2}\right]$ was obtained as a dark red brown solid $(0.075 \mathrm{~g}, 39 \%)$. Recrystallization from concentrated THF solution with ether diffusion gave dark red crystals used in the X-ray diffraction study. IR ( $\left.\nu_{\text {No }}\right): 1735 \mathrm{~s}, 1694 \mathrm{vs} \mathrm{cm}^{-1}$ (THF); 1741 s, $1697 \mathrm{vs} \mathrm{cm}^{-1}\left(\mathrm{CH}_{2} \mathrm{Cl}_{2}\right)$. UV-vis absorption spectrum (THF) $\left[\lambda_{\max }\right.$, $\left.\mathrm{nm}\left(\epsilon, \mathrm{M}^{-1} \mathrm{~cm}^{-1}\right)\right]$ : 452(1544), 360(3943), 342(5095). Anal. Calcd for $\mathrm{C}_{48} \mathrm{H}_{40} \mathrm{O}_{2} \mathrm{~N}_{3} \mathrm{P}_{2} \mathrm{FeSe}_{2}$ : N, 1.28; C, 60.4; H, 4.15. Found: $\mathrm{N}, 1.34$; $\mathrm{C}, 60.2 ; \mathrm{H}, 4.13$.

Preparation of $\left[(\mathrm{ON}) \mathrm{Ni}\left(\mu-\mathrm{S}\left(\mathrm{CH}_{2}\right)_{2} \mathrm{~S}\left(\mathrm{CH}_{2}\right)_{2} \mathrm{~S}\right) \mathrm{Fe}(\mathrm{NO})_{2}\right]$ (2). Into a $100-\mathrm{mL}$ Schlenk flask were loaded the starting materials [PPN][Fe$\left.(\mathrm{NO})_{2}(\mathrm{SePh})_{2}\right](0.40 \mathrm{mmol}, 0.388 \mathrm{~g}), \mathrm{NaNO}_{2}(0.40 \mathrm{mmol}, 0.028 \mathrm{~g})$, and $\left[\mathrm{Ni}\left(\mu-\mathrm{S}\left(\mathrm{CH}_{2}\right)_{2} \mathrm{~S}\left(\mathrm{CH}_{2}\right)_{2} \mathrm{~S}\right)\right]_{2}(0.20 \mathrm{mmol}, 0.086 \mathrm{~g})$. A $30-\mathrm{mL}$ portion of $\mathrm{CH}_{2} \mathrm{Cl}_{2}$ was added to give a dark purple solution. The solution mixture was stirred at $50{ }^{\circ} \mathrm{C}$ overnight, after which $15 \mathrm{~mL}$ of hexane was added to precipitate the side products $[\mathrm{PPN}]\left[\mathrm{Fe}(\mathrm{NO}) \mathrm{Cl}_{3}\right]$ and $\mathrm{NaSePh}$. The resulting mixture was filtered and solvent was removed from the filtrate under vacuum. One milliliter of $\mathrm{CH}_{2} \mathrm{Cl}_{2}$ was added to redissolve the products and hexane $(12 \mathrm{~mL})$ was added to obtain a dark green solid isolated by filtration $(0.061 \mathrm{~g}, 43 \%)$. Recrystallization from ether gave green brown crystals which were soluble in hexane, THF, and methylene dichloride. IR $\left(\nu_{\mathrm{No}}\right): 1805 \mathrm{~m}, 1767 \mathrm{~s}, 1725 \mathrm{~s} \mathrm{~cm}^{-1}$ $\left(\mathrm{CH}_{2} \mathrm{Cl}_{2}\right) ; 1798 \mathrm{~m}, 1763 \mathrm{~s}, 1723 \mathrm{~s} \mathrm{~cm}^{-1}$ (THF). Absorption spectrum $\left(\mathrm{CH}_{2} \mathrm{Cl}_{2}\right)\left[\lambda_{\max }, \mathrm{nm}\left(\epsilon, \mathrm{M}^{-1} \mathrm{~cm}^{-1}\right)\right]:$ 491(519), 385(919). Anal. Calcd for $\mathrm{C}_{4} \mathrm{H}_{8} \mathrm{O}_{3} \mathrm{~N}_{3} \mathrm{~S}_{3} \mathrm{NiFe}$ : N, 11.78; C, 13.46; $\mathrm{H}, 2.26$. Found: $\mathrm{N}, 11.68$; C, 13.54; H, 2.21

Preparation of $(\mathrm{Ni}-1) \mathrm{Fe}(\mathrm{CO})(\mathrm{NO})_{2}$ and $(\mathrm{Ni}-1) \mathrm{Fe}(\mathrm{CO})_{2}(\mathrm{NO})_{2}$. To a stirred solution of (bme-daco)Ni(II), Ni-1 $(0.044 \mathrm{~g}, 0.15 \mathrm{mmol})$, in acetonitrile $(30 \mathrm{~mL})$ was added $\mathrm{Fe}(\mathrm{CO})_{2}(\mathrm{NO})_{2}(16 \mu \mathrm{L}, 0.16 \mathrm{mmol})$. The reaction was monitored immediately by IR to confirm the loss of bands for the starting material with formation of $(\mathbf{N i - 1}) \mathrm{Fe}(\mathrm{CO})(\mathrm{NO})_{2}$, THF solution spectra $\left(\mathrm{cm}^{-1}\right)$ : $\left(v_{\mathrm{CO}}\right) 2006 \mathrm{br} ;\left(\nu_{\mathrm{NO}}\right)$ : $1733 \mathrm{~s}, 1691 \mathrm{vs}$. After $1.5 \mathrm{~h}$ of stirring, the resulting red-brown solution had two $v_{\mathrm{NO}}$ bands at $1677(\mathrm{~ms})$ and $1630(\mathrm{~s}) \mathrm{cm}^{-1}$, as expected for (Ni-1)Fe(NO) based on the spectroscopy of the Osterloh et al. complex. ${ }^{4}$ Both compounds are thermally unstable and decomposed under vacuum; they dissolve in polar solvents such as THF and acetonitrile.

\section{Results and Discussion}

Syntheses and Molecular Structures. Presented in Scheme 1 is the reaction which led to dark red, crystalline $\left[\mathrm{PPN}^{+}\right][\mathrm{Fe}-$ $(\mathrm{NO})_{2}(\mathrm{SePh})_{2}{ }^{-}$. The molecular structure of the anion, Figure 1 , is that of a distorted tetrahedron, elongated along the $\mathrm{Se}-$ $\mathrm{Fe}-\mathrm{Se}$ and $\mathrm{N}-\mathrm{Fe}-\mathrm{N}$ edges. The nitrosyls are slightly bent $\left(\angle \mathrm{Fe}-\mathrm{N}-\mathrm{O}=169^{\circ}\right)$ and flared toward each other. ${ }^{6}$ The $\mathrm{Fe}-$ $\mathrm{SePh}$ average distance of 2.395(1) $\AA$ is significantly shorter than that of the six-coordinate fac- $\mathrm{Fe}(\mathrm{CO})_{3}(\mathrm{SePh})_{3}{ }^{-}(\mathrm{Fe}-\mathrm{Se}$ average $=2.459(2) \AA)^{11 \mathrm{a}}$ and tetrahedral $\left[\mathrm{Fe}(\mathrm{SePh})_{4}\right]^{2-}(\mathrm{Fe}-\mathrm{Se}$ average $=2.460(12) \AA) .{ }^{14}$ This is rationalized by the higher coordination

(10) (a) Harley-Mason, J. J. Chem. Soc. 1952, 146. (b) Baker, D. J.; Goodall, D. C.; Moss, D. S. Chem. Commun. 1969, 325.

(11) (a) Liaw, W.-F.; Lai, C.-H.; Chiang, M.-H.; Lee, C.-K.; Lee, G.-H.; Peng, S.-M. J. Chem. Soc., Dalton Trans. 1993, 2421. (b) Liaw, W.F.; Chiang, M.-H.; Liu, C.-J.; Harn, P.-J.; Liu, L.-K. Inorg. Chem. 1993, 32, 1536. (c) Liaw, W.-F.; Chen, C.-H.; Lee, C.-M.; Lin, G.Y.; Ching, C.-Y.; Lee, G.-H.; Peng, S.-M. J. Chem. Soc., Dalton Trans. 1998, 353

(12) Hieber, W.; Beutner, H. Z. Anorg. Allg Chem. 1963, 320, 101.

(13) Mills, D. K.; Reibenspies, J. H.; Darensbourg, M. Y. Inorg. Chem. 1990, 29, 4364

(14) McConnachie, J. M.; Ibers, J. A. Inorg. Chem. 1991, 30, 1770. 


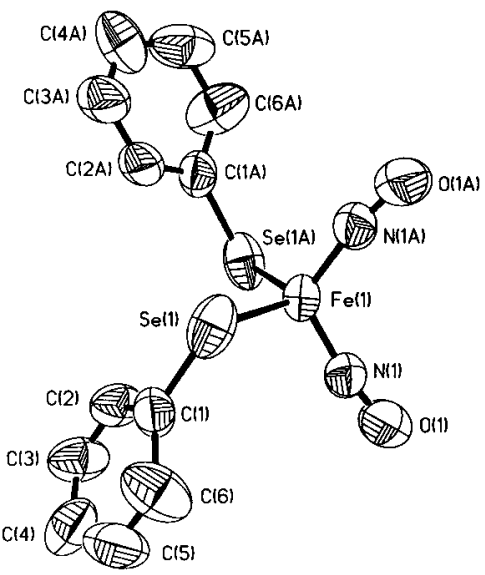

Figure 1. Labeling scheme for $\left[\mathrm{Fe}(\mathrm{NO})_{2}(\mathrm{SePh})_{2}\right]^{-}(\mathbf{1})$ with thermal ellipsoids drawn at the $50 \%$ probability level. $\mathrm{Fe}-\mathrm{Se}, 2.395(1) ; \mathrm{Fe}-$ $\mathrm{N}(1), 1.669(4) ; \mathrm{N}(1)-\mathrm{O}(1), 1.162(5) . \mathrm{Se}-\mathrm{Fe}-\mathrm{Se}(\mathrm{a}), 114.08(5) ; \mathrm{Se}-$ $\mathrm{Fe}-\mathrm{N}(1), 107.88(13) ; \mathrm{Se}-\mathrm{Fe}-\mathrm{N}(1 \mathrm{a}), 105.06(13) ; \mathrm{N}(1)-\mathrm{Fe}-\mathrm{N}(1 \mathrm{a})$, 117.20(19); $\mathrm{Fe}-\mathrm{N}(1)-\mathrm{O}(1), 169.2(4)$.

\section{Scheme 1}

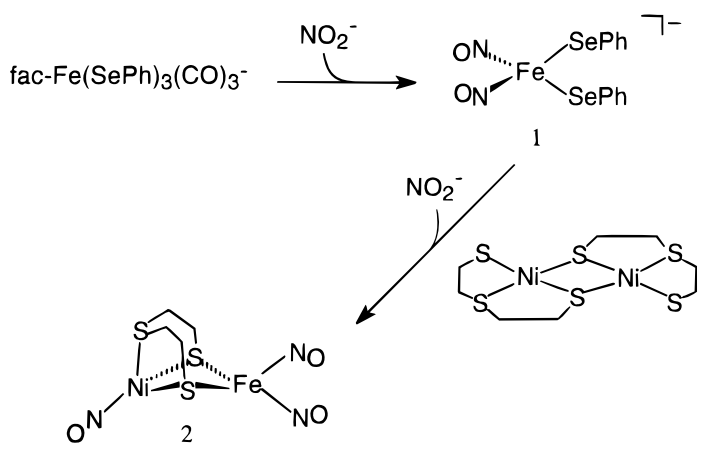

number of the former and higher anionic charge of the latter. Structural and spectroscopic features are the same for $\mathbf{1}$ and $\left[\mathrm{Fe}(\mathrm{NO})_{2}(\mathrm{SPh})_{2}\right]^{-} \cdot{ }^{15}$

Subsequent reaction of the $\left[\mathrm{Fe}(\mathrm{NO})_{2}(\mathrm{SePh})_{2}\right]^{-}$anion with dimeric $\left[\mathrm{Ni}\left(\mu-\mathrm{SCH}_{2} \mathrm{CH}_{2} \mathrm{SCH}_{2} \mathrm{CH}_{2} \mathrm{~S}\right)\right]_{2}$ in the presence of additional $\mathrm{NO}_{2}{ }^{-}$produced the neutral heterobimetallic $[(\mathrm{ON}) \mathrm{Ni}$ $\left.\left\{\left(\mu-\mathrm{SCH}_{2} \mathrm{CH}_{2}\right)_{2} \mathrm{~S}\right\} \mathrm{Fe}(\mathrm{NO})_{2}\right]$ complex 2 , as a thermally stable, dark green-brown solid isolated in $\approx 70 \%$ yield. Complex 2 is soluble in hexane and THF and forms slightly air-sensitive solutions in $\mathrm{CH}_{2} \mathrm{Cl}_{2}$. Crystals suitable for X-ray crystallography were grown from concentrated hexane solution and were found to be in the triclinic $\mathrm{P}^{\overline{1}}$ space group.

Figure 2 displays a thermal ellipsoid plot of the neutral $\mathrm{Ni}-$ Fe bimetallic complex 2 and selected distances and angles are given in the caption. The constraints of the bismercaptoethylenesulfide ligand generates $\approx 90^{\circ} \mathrm{S}_{\text {thioether }}-\mathrm{Ni}-\mathrm{S}_{\text {thiolate }}$ angles, ${ }^{16}$ enforcing a severe distortion from a tetrahedral at the four-coordinate nickel site. Nevertheless, the $\mathrm{NiS}_{2} \mathrm{Fe}$ core is minimally hinged (the angle between $\mathrm{NiS}_{2}$ and $\mathrm{FeS}_{2}$ planes $=$ $\left.162.8^{\circ}\right)$.

All $\mathrm{M}-\mathrm{S}_{\text {br thiolate }}$ distances of complex 2 are substantially the same, $2.29 \AA$, while the $\mathrm{Ni}-\mathrm{S}_{\text {thioether }}$ distance is $0.02-\AA$ shorter. The average $\mathrm{Fe}-\mathrm{S}-\mathrm{Ni}$ angle of $75.2^{\circ}$ and the $\mathrm{Fe}-\mathrm{Ni}$ distance of 2.8001(6) $\AA$ are similar to those of complex $\mathbf{4}, 76.11(4)^{\circ}$ and 2.797(1) $\AA$, respectively. (A stick drawing of complex 4 is found in Table 2.) The large $\angle \mathrm{S}_{\mathrm{br}}-\mathrm{Ni}-\mathrm{S}_{\mathrm{br}}$ of $103.94(3)^{\circ}$ and $\angle \mathrm{S}-\mathrm{Fe}-\mathrm{S}$ of $103.73(3)^{\circ}$ found in complex 2 however dramati-

(15) Strasdeit, H.; Krebs, B.; Henkel G. Z. Naturforsch. 1986, 41b, 1357

(16) Kaasjager, V. E.; Henderson, R. K.; Bouwman, E.; Lutz, M.; Spek, A. L.; Reedijk, J. Angew. Chem., Int. Ed. 1998, 37, 1668.

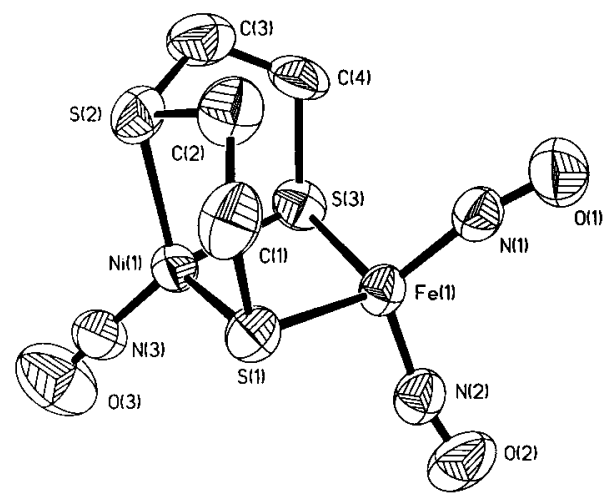

Figure 2. Labeling scheme for $\left[(\mathrm{ON}) \mathrm{Ni}\left(\mu-\mathrm{S}\left(\mathrm{CH}_{2}\right)_{2} \mathrm{~S}\left(\mathrm{CH}_{2}\right)_{2} \mathrm{~S}\right) \mathrm{Fe}(\mathrm{NO})_{2}\right]$ (2) with thermal ellipsoids drawn at the $50 \%$ probability level. $\mathrm{Fe}-$ $\mathrm{S}(1), 2.2907(9) ; \mathrm{Fe}-\mathrm{S}(3), 2.3039(9) ; \mathrm{Fe}-\mathrm{N}(1), 1.670(2) ; \mathrm{Fe}-\mathrm{N}(2)$, 1.674(3); $\mathrm{N}(1)-\mathrm{O}(1), 1.163(3) ; \mathrm{N}(2)-\mathrm{O}(2), 1.159(3) ; \mathrm{Ni}-\mathrm{S}(1), 2.2947-$ (9); $\mathrm{Ni}-\mathrm{S}(2), 2.2701(9) ; \mathrm{Ni}-\mathrm{S}(3), 2.2931(9) ; \mathrm{Ni}-\mathrm{N}(3), 1.644(2)$; $\mathrm{N}(3)-\mathrm{O}(3), 1.119(3) ; \mathrm{Ni} \cdots \mathrm{Fe}, 2.8001(6) . \mathrm{S}(1)-\mathrm{Fe}-\mathrm{S}(3), 103.73(3)$; $\mathrm{S}(1)-\mathrm{Fe}-\mathrm{N}(1), 114.88(9) ; \mathrm{S}(1)-\mathrm{Fe}-\mathrm{N}(2), 106.02(9) ; \mathrm{N}(1)-\mathrm{Fe}-\mathrm{N}(2)$, 115.06(12); $\mathrm{S}(1)-\mathrm{Ni}-\mathrm{S}(2), 91.67(3) ; \mathrm{S}(1)-\mathrm{Ni}-\mathrm{S}(3), 103.94(3) ; \mathrm{S}(1)$ $\mathrm{Ni}-\mathrm{N}(3), 120.53(10) ; \mathrm{S}(2)-\mathrm{Ni}-\mathrm{S}(3), 92.31(4) ; \mathrm{S}(2)-\mathrm{Ni}-\mathrm{N}(3), 126.69$ (9); $\mathrm{S}(3)-\mathrm{Ni}-\mathrm{N}(3), 115.83(10) ; \mathrm{Fe}-\mathrm{S}(1)-\mathrm{Ni}, 75.28(3) ; \mathrm{Fe}-\mathrm{S}(3)-$ $\mathrm{Ni}, 75.05(3)$; $\mathrm{Fe} \mathrm{N}(1)-\mathrm{O}(1), 166.21(23) ; \mathrm{Fe}-\mathrm{N}(2)-\mathrm{O}(2), 167.3(3)$; $\mathrm{Ni}-\mathrm{N}(3)-\mathrm{O}(3), 175.1(3)$.

cally differ from the analogous features in complex $4,81.46(6)^{\circ}$ and $74.10(6)^{\circ}$, respectively. Further appropriate comparisons lie in the $\mathrm{Fe}-\mathrm{N}$ and $\mathrm{N}-\mathrm{O}$ parameters; the $\mathrm{Fe}-\mathrm{N}$ bond distances (average $1.67 \AA$ ) are not disturbed by the change of donor sets in complexes $\mathbf{1}$ versus $\mathbf{2}$ which are very slightly longer than the $1.65-\AA$ average seen for 4 . The $\mathrm{Fe}-\mathrm{NO}$ bonds are off linearity by an average of $\approx 10^{\circ}$ and, as previously noted for complex $\mathbf{1}$, they bend toward each other.

The Ni-NO distance (1.644(2) $\AA$ ) in complex 2 is comparable with the terminal $\mathrm{Ni}-\mathrm{NO}$ of $1.653(4) \AA$ in $[\mathrm{Ni}(\mathrm{NO})$ $\left.(\mathrm{PTA})_{3}\right]^{+}(\mathrm{PTA}=1,3,5$-triaza-7-phosphaadamantane $) ;{ }^{17}$ the nitrosyl ligand is coordinated in a nearly linear mode with the $\angle \mathrm{Ni}-\mathrm{N}(3)-\mathrm{O}(3)=175.1(3)^{\circ}$. Together with similar $v(\mathrm{NO})$ values found for complexes 2 and $\left[\mathrm{Ni}(\mathrm{NO})(\mathrm{PTA})_{3}\right]^{+}$, vide infra, we conclude the site is best described as $\mathrm{NO}^{+}$coordinated to nickel(0).

Spectroscopic and Electrochemical Measurements. Complexes $\mathbf{1}, \mathbf{2}$, and $\mathbf{3}$, the $\left\{\mathrm{Fe}(\mathrm{NO})_{2}\right\}^{9}$ species, in Table 2, have an odd number of electrons and were found to have similar EPR properties: a single isotropic signal with no hyperfine coupling to the NO ligands. The $g$ values of 2.021, 2.021, and 2.028, for $\mathbf{1}, \mathbf{2}$, and $\mathbf{3}$, respectively, are consistent with halogenonitrosyl iron complexes, $\left[\mathrm{X}_{2} \mathrm{Fe}(\mathrm{NO})_{2}\right]^{-}(\mathrm{X}=\mathrm{Cl}, \mathrm{Br}, \mathrm{I})$ which also have tetrahedral geometry and an electron assignment of $\left\{\mathrm{Fe}(\mathrm{NO})_{2}\right\}^{9}$ with $S=1 / 2 .{ }^{18}$ Weaker EPR signals, assumed to be due to impurities, were observed for solutions of complexes $\mathbf{4}, \mathbf{5}$, and 6 (spin quantitations of $0.07-0.10$ spin per molecule as compared to $\approx 1.0$ for $\mathbf{1}, \mathbf{2}$, and $\mathbf{3}$ ).

On treatment of the complex 2 with 1 equiv of $\mathrm{Ce}^{\mathrm{IV}}$ (as cerium ammonium nitrate), the EPR signal at $g=2.021$ was lost. Addition of the weak reductant, $\mathrm{Cp}_{2} \mathrm{Co}$, produced no change in the EPR spectrum. However, addition of the $\mathrm{LiHBEt}_{3}$ reagent to the EPR sample tube produced an axial signal of $g=2.602$ and 2.018. This product has not been identified.

(17) $\mathrm{PTA}=$ phosphotriazaadamantane, a neutral P-donor ligand. Darensbourg, D. J.; Decuir, T. J.; Stafford, N. W.; Robertson, J. B.; Draper, J. D.; Reibenspies, J. H.; Kathó, A.; Joó, F. Inorg. Chem. 1997, 36, 4218.

(18) Connelly, N. G.; Gardner, C. J. Chem. Soc., Dalton Trans. 1976, 1525. 
Table 2. Selected Structure and Infrared Data for Dichalcogenide $\mathrm{Fe}(\mathrm{NO})_{2}$ Derivatives $\left\{\mathrm{Fe}(\mathrm{NO})_{2}\right\}^{9,10}$ Based on Enemark-Feltham Notation $^{6}$

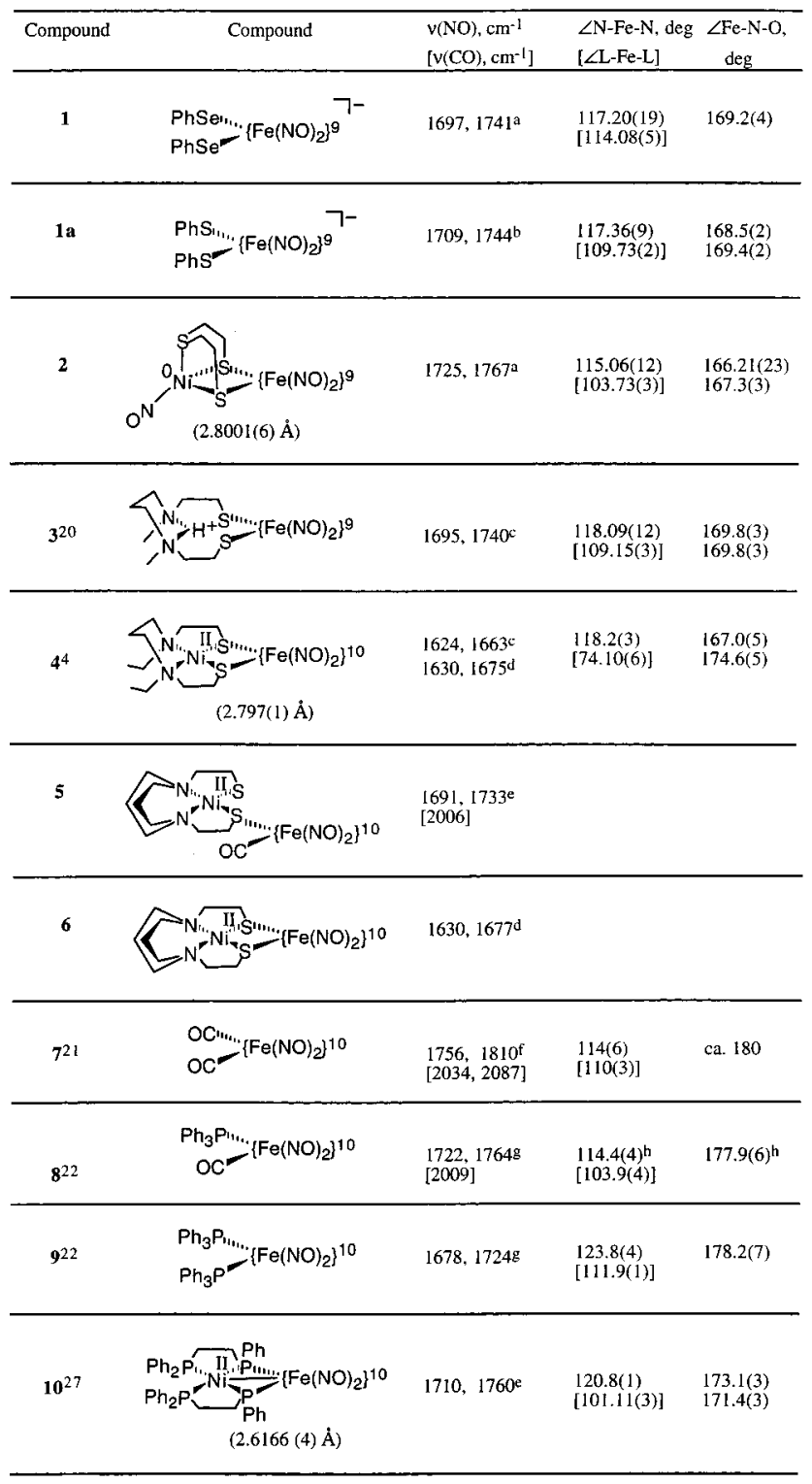

${ }^{a}$ Dichloromethane. ${ }^{b}$ CsI. ${ }^{c}$ KBr. ${ }^{d}$ Acetonitrile. ${ }^{e}$ THF. ${ }^{f}$ Cyclohexane. ${ }^{g}$ Tetrachloroethylene. ${ }^{h}$ Shown are average values.

As noted in Table 2, the $\mathrm{CH}_{2} \mathrm{Cl}_{2}$ solution spectrum of the neutral heterobimetallic compound $\mathbf{2}$ shows three infrared bands in the $\nu_{\mathrm{NO}}$ region. The highest frequency band at $1805 \mathrm{~cm}^{-1}$ is identical to the $v_{\mathrm{NO}}$ band of the tetracoordinate, pseudotetrahedral $\mathrm{Ni}(0)$ nitrosyl complex $\left[\mathrm{Ni}(\mathrm{NO})(\mathrm{PTA})_{3}\right]^{+}\left(v_{\mathrm{NO}}=1805\right.$ $\mathrm{cm}^{-1}$ in $\left.\mathrm{CH}_{2} \mathrm{Cl}_{2}\right)$; thus, we can project an electron donor ability of the $\left(\mu-\left(\mathrm{SCH}_{2} \mathrm{CH}_{2}\right)_{2} \mathrm{~S}\right) \mathrm{Fe}(\mathrm{NO})_{2}$ unit to $[\mathrm{NiNO}]^{+}$to be the same as that of the $\mathrm{P}$-donor ligands, assuming an oxidation state of zero for nickel and the presence of $\mathrm{NO}$ as $\mathrm{NO}^{+} .{ }^{17}$ That is, the three $\mathrm{S}$ donors comprised of a $\left\{\mathrm{Fe}(\mathrm{NO})_{2}\right\}^{9}$-modified dithiolate and the one thioether is equivalent to three $\mathrm{P}$ donors of the phosphotriazaadamantane ligand, PTA.

The lower energy NO bands of 2 are shifted by $\approx+30 \mathrm{~cm}^{-1}$ from those of the anionic monomeric precursor, $\mathrm{Fe}(\mathrm{NO})_{2}(\mathrm{SePh})_{2}{ }^{-}$. Known to serve as a reporter of electron density at iron similarly to $\mathrm{CO},{ }^{19}$ the shifts in $\mathrm{NO}$ frequencies reflect a variation in negative charge on the $\mathrm{Fe}(\mathrm{NO})_{2}$ unit as follows: $\mathbf{4}<\mathbf{3} \sim \mathbf{1}<$

(19) Horrocks, W. D.; Taylor, R. C. Inorg. Chem. 1963, 2, 723.
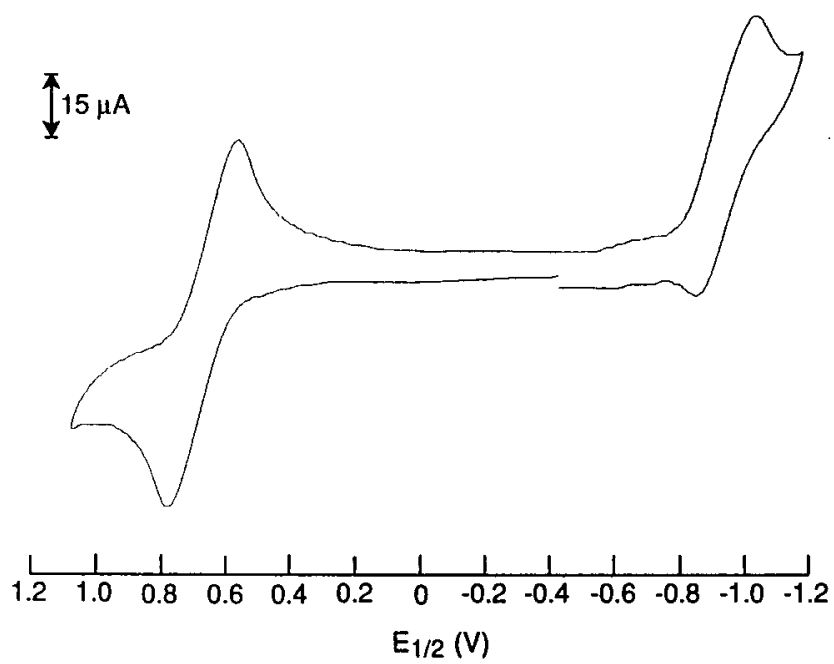

Figure 3. Cyclic voltammogram of a $2.5-\mathrm{mV}$ solution of complex 2 in $0.1 \mathrm{M}$ TBAHFP/ $\mathrm{CH}_{2} \mathrm{Cl}_{2}$ with a glassy carbon working electrode at a scan rate of $200 \mathrm{mV} / \mathrm{s}$.

2. ${ }^{4,20}$ Thus, the charge separation indicated by the formal oxidation states of the heterobimetallic complexes $2(\mathrm{Ni} /\{\mathrm{Fe}-$ $\left.\left.(\mathrm{NO})_{2}\right\}^{9}\right)$ and $4\left(\mathrm{Ni}{ }^{\mathrm{II}} /\left\{\mathrm{Fe}(\mathrm{NO})_{2}\right\}^{10}\right)$ is reflected in the $v_{\mathrm{NO}}$ values. The similarity of $v_{\mathrm{NO}}$ values in the $\mathrm{Fe}(\mathrm{NO})_{2}$ units of complexes $\mathbf{1}$ and $\mathbf{3}$, despite the negative charge on the former, is rationalized by the firm localization of $\mathrm{H}^{+}$on the two nitrogen bases, as indicated in the structure drawn for 3 . The higher $v_{\mathrm{NO}}$ values of 2 versus 3 would then imply that the $\mathrm{Ni}^{0}\left(\mathrm{NO}^{+}\right)$unit substantially neutralizes the cis thiolate negative charges, and the $\left[(\mathrm{ON}) \mathrm{Ni}^{0} \mathrm{~S}_{3}\right]^{-}$unit serves as a bidentate donor ligand of -1 charge to the $\left\{\mathrm{Fe}(\mathrm{NO})_{2}\right\}^{9}$ unit.

Figure 3 displays the cyclic voltammogram (CV) of complex 2 with its two quasi-reversible redox events centered at +690 and $-970 \mathrm{mV}$. Because the $\mathrm{CV}$ of $[\mathrm{PPN}]\left[(\mathrm{PhSe})_{2}\left\{\mathrm{Fe}(\mathrm{NO})_{2}\right\}^{9}\right]$ has a reduction feature at $-1160 \mathrm{mV}$, the $-970-\mathrm{mV}$ event of complex 2 is assumed to be due to the $\left\{\mathrm{Fe}(\mathrm{NO})_{2}\right\}^{9} /\left\{\mathrm{Fe}(\mathrm{NO})_{2}\right\}^{10}$ couple. With this assignment, we conclude that the anionic $(\mathrm{ON}) \mathrm{Ni}(0)$-dithiolate unit donates slightly less electron density to the $\left\{\mathrm{Fe}(\mathrm{NO})_{2}\right\}^{9}$ unit as compared to the two phenylselenide donors and stabilizes this event by $190 \mathrm{mV}$. This result is consistent with the $v(\mathrm{NO})$ values in the IR spectra as discussed above. The quasi-reversible anodic event at $+687 \mathrm{mV}$ could be assigned to the $\left\{\mathrm{Fe}(\mathrm{NO})_{2}\right\}^{9} /\left\{\mathrm{Fe}(\mathrm{NO})_{2}\right\}^{8}$ couple, consistent with the observed loss of the EPR signal of chemically oxidized 2. Alternatively, assignment to a nickel-based oxidation, the $\mathrm{Ni}^{\mathrm{O} / \mathrm{I}}$ couple, would have to invoke coupling of the $\left\{\mathrm{Fe}(\mathrm{NO})_{2}\right\}^{9}$ and the $\mathrm{Ni}^{\mathrm{I}}\left(d^{9}\right)$ centers to account for the loss of paramagnetism and the EPR signal.

\section{Further Comments}

The assignment of formal oxidation levels to the $\mathrm{Fe}(\mathrm{NO})_{2}$ units compared in this study was done in an effort to describe the electron-donating abilities of the ancillary ligands within a similar framework. With this approach, we are able to reference the nickel(0)dithiolate, compound 2, and nickel(II)dithiolate ligands, compounds $\mathbf{4 , 5}$, and $\mathbf{6}$, with respect to mononuclear complexes with rather unambiguous additional ligands to $\mathrm{Fe}$ $(\mathrm{NO})_{2} \cdot{ }^{21,22}$ The following conclusions are made:

(20) Baltusis, L. M.; Karlin, K. D.; Rabinowitz, H. N.; Dewan, J. C.; Lippard, S. J. Inorg. Chem. 1980, 19, 2627.

(21) (a) Brockway, L. O.; Anderson, J. S. Trans. Faraday Soc. 1937, 38, 1233. (b) Hedberg, L.; Hedberg, K.; Satija, S. K. Swanson, B. I. Inorg. Chem. 1985, 24, 2766.

(22) Albano, V. G.; Araneo, A.; Bellon, P. L.; Ciani, G.; Manassero, M. J. Organomet. Chem. 1974, 67, 413. 
(1) Two oxidation levels, $\left\{\mathrm{Fe}(\mathrm{NO})_{2}\right\}^{9}$ and $\left\{\mathrm{Fe}(\mathrm{NO})_{2}\right\},{ }^{10}$ are observed in the heterobimetallic molecular units examined in this work. The paradigms for the former are $(\mathrm{PhS})_{2} \mathrm{Fe}(\mathrm{NO})_{2}{ }^{-}$ and $(\mathrm{PhSe})_{2} \mathrm{Fe}(\mathrm{NO})_{2}{ }^{-}$while that of the latter is $(\mathrm{CO})_{2} \mathrm{Fe}(\mathrm{NO})_{2}$. The $\pi$-donor ability of thiolate (or selenoate) stabilizes the former $\left\{\mathrm{Fe}(\mathrm{NO})_{2}\right\}^{9}$ or oxidized form, while the $\pi$-accepting ability of $\mathrm{CO}$ stabilizes the latter, reduced form.

(2) The oxidation level of $\mathrm{Fe}(\mathrm{NO})_{2}$ is the primary determinant of the $v(\mathrm{NO})$ position. Within a series of the same oxidation level, the $v(\mathrm{NO})$ reporter shows a sensitivity to ancillary ligands to $\left\{\mathrm{Fe}(\mathrm{NO})_{2}\right\}$ similarly to $v(\mathrm{CO})$ as described in classic studies such as that of Horrocks and Taylor in a homologous series of $\mathrm{Co}(\mathrm{NO})(\mathrm{CO})\left(\mathrm{PR}_{3}\right)$ complexes. ${ }^{19}$ In an earlier study, we referenced the nickel(II) dithiolate, (bme-daco)Ni as a S-donor ligand to $\mathrm{Fe}^{0}(\mathrm{CO})_{4}$ relative to $\left(\mathrm{Ph}_{3} \mathrm{P}\right) \mathrm{Fe}(\mathrm{CO})_{4}$ using the noncontroversial $\mathrm{CO}$ ligand as a spectroscopic probe. ${ }^{23}$ There, we found the monodentate metallothiolate ligand to be a better donor, shifting the $v(\mathrm{CO})$ values negatively on average by $\approx 30 \mathrm{~cm}^{-1}$ from $\left(\mathrm{Ph}_{3} \mathrm{P}\right) \mathrm{Fe}(\mathrm{CO})_{4}$.

(3) The formation and the $v(\mathrm{NO})$ values of the NiFe bimetallic compound $\mathbf{2}$ is consistent with a dichalcogenide derivative of $\left\{\mathrm{Fe}(\mathrm{NO})_{2}\right\}^{9}$ that is partially charge-neutralized by interaction of a single cationic charge, that is, $[\mathrm{Ni}(\mathrm{NO})]^{+}$. This gives rise to the highest $v(\mathrm{NO})$ frequency of the $\left\{\mathrm{Fe}(\mathrm{NO})_{2}\right\}^{9}$ series. Alternatively, the heterometallic may be described as a $\left[\mathrm{S}^{\prime} \mathrm{S}_{2} \mathrm{Ni}\left(\mathrm{NO}^{+}\right)\right]^{-}$moiety bound by an interacting $\left\{\mathrm{Fe}(\mathrm{NO})_{2}\right\}^{9}$ unit which effectively softens the thiolate donors of $\mathrm{S}\left(\mathrm{CH}_{2} \mathrm{CH}_{2}\right.$ $\left.\mathrm{S}^{-}\right)_{2}$.

(4) The $v(\mathrm{NO})$ positions of compounds $\mathbf{4}, \mathbf{5}$, and $\mathbf{6}$, those containing the $\left\{\mathrm{Fe}(\mathrm{NO})_{2}\right\}^{10}$ moiety, Table 2 , are consistent with those of compounds $\mathbf{7}, \mathbf{8}$, and $\mathbf{9}$ given the established donor ability of NiSR versus $\mathrm{PPh}_{3}$ discussed above. That is, the nickel thiolate is a better donor than phosphine, producing the lowest observed $v(\mathrm{NO})$ in the entire series for compounds $\mathbf{4}$ and $\mathbf{6}$.

Thus, for the purpose of interpreting the IR spectra, the $\mathrm{Ni}^{\mathrm{II}}(\mu$ $\mathrm{SR})_{2} \mathrm{Fe}(\mathrm{NO})_{2}$ and the $\mathrm{Ni}^{0}(\mu-\mathrm{SR})_{2} \mathrm{Fe}(\mathrm{NO})_{2}$ complexes may be viewed as mononuclear $\mathrm{Fe}(\mathrm{NO})_{2}$ centers with ligands (i.e., thiolates) modified by distal metal interactions. ${ }^{24}$ The oxidation level of the $\mathrm{Fe}(\mathrm{NO})_{2}$ unit may be rationalized according to the ability of the chalcogenide (or metal-modified chalcogenide) ligand to stabilize the oxidized, $\left\{\mathrm{Fe}(\mathrm{NO})_{2}\right\},{ }^{9}$ or reduced, $\{\mathrm{Fe}-$ $\left.(\mathrm{NO})_{2}\right\},{ }^{10}$ forms. A $2+$ charge on the distal metal, as in the $\mathrm{Ni}^{\mathrm{II}}$-bound dichalcogenide, creates neutral sulfur donor sites and stabilizes the electron-rich or reduced form, as does $\mathrm{CO}$ or $\mathrm{PR}_{3}$. The $\left[\mathrm{Ni}^{0} \mathrm{NO}^{+}\right]$unit effectively generates a monoanionic dithiolate ligand donor set, which stabilizes the oxidized form. Interestingly, both have the same $\mathrm{Ni}-\mathrm{Fe}$ distances of $2.8 \AA$, but distinctly different hinge angles of the $\mathrm{Ni}(\mu-\mathrm{SR})_{2} \mathrm{Fe}$ unit, $104.6^{\circ}$ for complex 4 and $162.8^{\circ}$ for compound 2 . The maintenance of the same $\mathrm{Ni}-\mathrm{Fe}$ distance is possible because the $\angle \mathrm{S}-\mathrm{Fe}-\mathrm{S}$ and $\angle \mathrm{S}-\mathrm{Ni}-\mathrm{S}$ in the core $\mathrm{NiS}_{2} \mathrm{Fe}$ unit open by $\approx 30^{\circ}$ on going from the butterfly structure of $\mathbf{4}$ to the roughly planar structure of 2 , with a concomitant shift of the $\mathrm{Fe}(\mathrm{NO})_{2}$ unit relative to the $\mathrm{NiS}_{2}$ plane.

Such geometric differences as determined by the nickel oxidation state in $\mathbf{4}$ versus that in $\mathbf{2}$ demand ligands capable of

(23) Lai, C.-H.; Reibenspies, J. H.; Darensbourg, M. Y. Angew. Chem., Int. Ed. Engl. 1996, 35, 2390.

(24) Musie, G.; Farmer, P. J.; Tuntulani, T.; Reibenspies, J. H.; Darensbourg, M. Y. Inorg. Chem. 1996, 35, 2176.

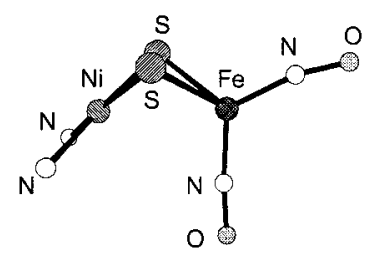

4

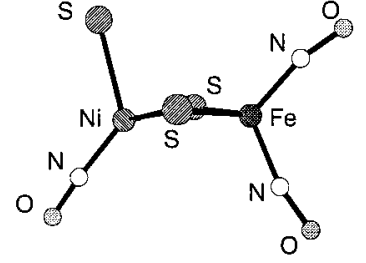

2 matching the geometrical requirement of the $\mathrm{Ni}(\mu-\mathrm{SR})_{2} \mathrm{Fe}$ unit as well as maintaining the preferred coordination number of the nickel. One would expect the protein's cysteinyl sulfurs which bridge the $\mathrm{Ni}-\mathrm{Fe}$ active site of $[\mathrm{NiFe}] \mathrm{H}_{2}$ ases to be capable of such flexibility. In fact, as observed in the protein crystal structures, the irregular orientation of the two terminal and two bridging CysS about nickel (pseudo-tetrahedral, or distorted, open-site square pyramid) could indicate a balance of geometrical requirements for different redox levels of nickel in different states of the enzyme. In small molecule model chemistry, two different ligands are required to mimic the effect. [It should be noted that the usefulness of the $\left(\mu-\mathrm{SCH}_{2} \mathrm{CH}_{2}\right)_{2} \mathrm{~S}$ ligand, was previously recognized in the preparation of a binuclear structural model for $\mathrm{Fe}$ only hydrogenase. ${ }^{16}$ ]

Electron coupling through the $2.8-\AA \mathrm{Ni}-\mathrm{Fe}$ distances found in the heterometallics with the $\mathrm{Fe}(\mathrm{NO})_{2}$ unit is expected, but not yet established. The $\mathrm{Ni}-\mathrm{Fe}$ distances in $\mathrm{Ni}{ }^{\mathrm{II}}-\mathrm{Fe}^{\mathrm{II}}$ heterometallics that do not contain the $\mathrm{Fe}(\mathrm{NO})_{2}$ unit are $\approx 3.0 \AA$ or larger. ${ }^{22,25,26}$ Interestingly, the natural heterobimetallic found in the $[\mathrm{NiFe}] \mathrm{H}_{2}$ ase enzyme active site has a $\mathrm{Ni}-\mathrm{Fe}$ distance of $2.9 \AA{ }^{1}$ The much shorter distance of $2.6 \AA$ in compound 10, ${ }^{27}$ listed in Table 2 as $\mathrm{Ni}^{\mathrm{II}}\left\{\mathrm{Fe}(\mathrm{NO})_{2}\right\},{ }^{10}$ probably implies a NiFe bond character and an assignment of $\mathrm{Ni}^{\mathrm{I}}\left\{\mathrm{Fe}(\mathrm{NO})_{2}\right\}^{9}$ would be equally, if not more, realistic.

Finally, it is noted that the usual exchange of two NO donor ligands for three two-electron donors such as $\mathrm{CO}$ and $\mathrm{CN}^{-}$ produces a fragment, $\mathrm{Fe}(\mathrm{NO})_{2}$, that could be interchangeable with isolobal $\mathrm{Fe}(\mathrm{CO})(\mathrm{CN})_{2}$, recently established as important in the hydrogenases. Because all three diatomic ligands have infrared stretches in the same region, isotopic labeling should be a requirement for confidence in spectroscopic assignments and vibrational studies.

Acknowledgment. The authors acknowledge the financial support of the National Science Council (Taiwan to W.F.L. and S.M.P.) and the National Science Foundation (U.S.A., CHE9812355 to M.Y.D.). We are grateful for the assistance of HuayKeng Loke in the EPR measurements, to Jason Smee for information retrieval and computer display, and to Dr. Frank Osterloh for his helpful critique of the manuscript.

Supporting Information Available: Tables of crystal data and experimental conditions for the X-ray studies, atomic coordinates and $B_{\text {eq }}$ values, complete listings of bond lengths and bond angles, and anisotropic temperature factors for $[\mathrm{PPN}]\left[\mathrm{Fe}(\mathrm{NO})_{2}(\mathrm{SePh})_{2}\right]$ and $[(\mathrm{ON})-$ $\left.\left.\mathrm{Ni}\left(\mu-\mathrm{S}\left(\mathrm{CH}_{2}\right)_{2} \mathrm{SCH}_{2}\right)_{2} \mathrm{~S}\right) \mathrm{Fe}(\mathrm{NO})_{2}\right]$. This material is available free of charge via the Internet at http://pubs.acs.org.

\section{IC990631Y}

(25) Mills, D. K.; Hsiao, Y. M.; Farmer, P. J.; Atnip, E. V.; Reibenspies, J. H.; Darensbourg, M. Y. J. Am. Chem. Soc. 1991, 113, 1421.

(26) Colpas, G. J.; Day, R. O.; Maroney, M. J. Inorg. Chem. 1992, 31, 5053.

(27) Chau, C. N.; Wojcicki, A.; Calligaris, M.; Nardin, G. Inorg. Chem. Acta 1990, 168, 105. 